Journal of Primary Education
$9(3)(2020): 311-320$
UNNES
https://journal.unnes.ac.id/sju/index.php/jpe

\title{
Critical Thinking Skills Reviewed from Communication Skills of the Primary School Students in STEM-Based Project-Based Learning Model
}

\author{
Zaini Oktavia $^{1 凶}$, Saiful Ridlo ${ }^{2}$
}

DOI: https://doi.org/10.15294/jpe.v9i3.27573

1. SD Negeri 3 Pakis, Kecamatan Kradenan, Kabupaten Grobogan

${ }^{2}$ Pascasarjana, Universitas Negeri Semarang, Indonesia

\begin{tabular}{l}
\hline Article Info \\
\hline History Articles \\
Received: \\
30 February 2020 \\
Accepted: \\
29 March 2020 \\
Published: \\
31 May 2020 \\
\hline Keywords: \\
Critical thinking Skills, \\
Communication Skills, \\
STEM-based Project- \\
Based Learning
\end{tabular}

\begin{abstract}
Critical thinking skills are important to practice early on in elementary school. It is believed that STEM based education could trigger the students to more critical. Individuals who have critical thinking skills will be able to communicate well. Many research results show that critical thinking skills can be stimulated by applying project-based learning in class. This research aims to describe critical thinking skills based on communication skills by using STEMbased Project-Based Learning. The research is a mixed-methods study. The population of this research consisted of fifth graders of Public Primary School 3 Pakis. The research instruments used were critical thinking skills tests, communication skills questionnaires and interview guidelines. The quantitative data was selected by purposive sampling technique. The qualitative data was based on the communication skills levels: high, moderate, and low. Based on the triangulation data it shows that students with high critical thinking skills reached the aspect of analyzing arguments; the moderate level could achieved simple aspects of explanation; while the lower level critical thinker only reaches the aspect of focusing questions. The STEM approach applied in project-based learning is able to encourage students to be able to communicate verbally and improve their critical thinking skills in solving problems.
\end{abstract}

\footnotetext{
Correspondence address:

Simo RT 07 RW 01 Kec. Kradenan, Kab. Grobogan, Jawa Tengah

E-mail: zainioktavia26@gmail.com
} 


\section{INTRODUCTION}

In education, the direct training and development process of human resources will be useful to internalize the required skills in this century (Ongardwanich, Kanjanawasee, \& Tuipae, 2015). One of the aspects is critical thinking skills to respond to various learning evaluation problems engaged by students. Thus, it helps students succeed in achieving their educational objectives.

Critical thinking skills in learning is important for students to connect concept and materials so they could understand and solve problems in the class orderly and correctly (Wijayanti, Pudjawan, \& Margunayasa, 2015). Students are considered able to think critically if they meet the indicators, such as (1) analyzing the argument, (2) focusing on questions, (3) asking and answering questions, (4) creating and determining the consideration result, (5) providing a simple explanation, (6) concluding, and (7) examining the similarities and drawing a conclusion (Ennis, 2011).

Learning with PjBL learning models can improve students' critical thinking skills (Mutakinati, Anwari, \& Kumano. 2018). In line with this research from Hartini (2017), it shows that PjBL can increase $65 \%$ of students' critical thinking skills. The increase in results is due to a new learning model that makes students more intense in participating in learning. Meanwhile, according to Lestari, Astuti, \& Darsono, (2018) learning with the STEM-based Project approach is able to provide effective improvements for students. The STEM approach can improve student learning outcomes even though research requires 8 learning meetings for one material (Siregar, Rachmadtullah, Pohan, \& Zulela 2019). Therefore, in this study the researcher combined the PjBL model with the STEM approach which became the PjBL-STEM based on the results of previous studies that were proven to be able to improve critical thinking skills.

PISA results in 2018 for scientific skills placed Indonesia in the $70^{\text {th }}$ rank with score 396 from the whole average score, 489, from 78 countries. It shows that Indonesia still has low scientific skills. Therefore, more innovative and stimulating learning models were needed to improve the scientific skills. One of them is Science, Technology, Engineering, Mathematics based Project Based Learning (STEM-PjBL).

STEM-PjBL is a learning process that combines Project-Based Learning ( $\mathrm{PjBL}$ ) and the Scientific, Technology, Engineering, and Mathematics Approach. The implementation of $\mathrm{PjBL}$ is recommended by the government based on the applied curriculum. $\mathrm{PjBL}$ is defined as monitored learning that its problem-solving process is based on scientific investigation methods. Thus, students are encouraged to learn concepts and principles through their explanations and to construct with their obtained concept (Gandi, Haryani, \& Setiawan, 2019).

The use of the STEM approach, according to Becker, \& Park (2011), could provide a positive influence and improve the learning outcomes. Besides that, the implementation of the STEM approach, by era development, it demands students to master $4 \mathrm{C}$ skills. They are creativity, critical thinking, collaboration, and communication (Jauhariyyah, Suwono, \& Ibrohim, 2017) Therefore, the STEM-based Project-Based Learning in this research is a combination of problems correlated to STEM skills. It is created as a project in the students' critical thinking skills problems in learning. Han, Capraro, \& Capraro (2015), stated that students are demanded to complete real problems in a group.

In the STEM approach, there is a communication skills. Communication skills is the most basic skills to master by individuals by the time of the physical development and the mental growth for human (Nugroho \& Nurcahyo, 2018). An excellent communication skills could improve the students' spirits in learning and discipline to solve high order thinking learning problems for students (Rochmawati, Wiyanto, \& Ridlo, 2019). Besides, low learning outcomes are caused by a lack of confidence and information owned by 
students to discuss (Purvis, Neill, \& Sutherland, 2014).

Based on the background mentioned, the problem formulation for this study are (1) is the STEM-based Project-Based Learning effective to improve students' critical thinking? (2) is their improvement of the critical thinking skills after the learning, and (3) how the description of the students' critical thinking skills based on communication skills is. This research aims to find out the STEM-based PjBL effectiveness and analyze the students' critical thinking skills based on the students' communication skills in Science.

\section{METHODS}

This study was a mixed-methods research with sequential explanatory type by combining quantitative and qualitative researches. Mixedmethods is as procedure to collect, analyze, and combine both quantitative and qualitative methods into a research or series of researches to understand the problem. First stage conducted in this study are quantitative data collection and analysis. The quantitative design applies one group pretest-posttest with the STEM-based Project-Based Learning under human respiratory system topic. The qualitative research focuses on eliciting information and describing critical thinking skills based on the students' communication skills.

This research was conducted at Public Primary School Pakis 3, in the odd semester of
Academic Year 2019/2020. The population were consisted of 34 -fifth graders. The research samples of the quantitative method apply a saturated sample. It means all population were taken as the samples. Meanwhile, the qualitative study samples applies purposive sampling by considering each group category of the student communication skills, started from high, moderate, and low level.

The applied research instruments $\mathrm{w}$ communication skills questioners and critical thinking skills tests. The type of critical thinking test was essay test that combined by STEM with seven indicator. The indicators employed were (1) Focusing on questions, (2) Analyzing arguments, (3) Asking and answering questions, (4) Simple explanations, (5) Making and determining the results of considerations, (6) make conclusions, (7) Testing conclusions. There are 5 number of question in test. To analyze the initial and final data, the $\mathrm{N}$-gain test was applied. In the analysis stage of the qualitative research data, it applies data reduction, display, and conclusion.

\section{RESULTS AND DISCUSSION}

The results of the research with the PjBLSTEM shown in Figure 1. STEM approach is the steps in making the project. Students in group were asked to used recycled material and then processed them into a product as a learning media related to the respiratory system

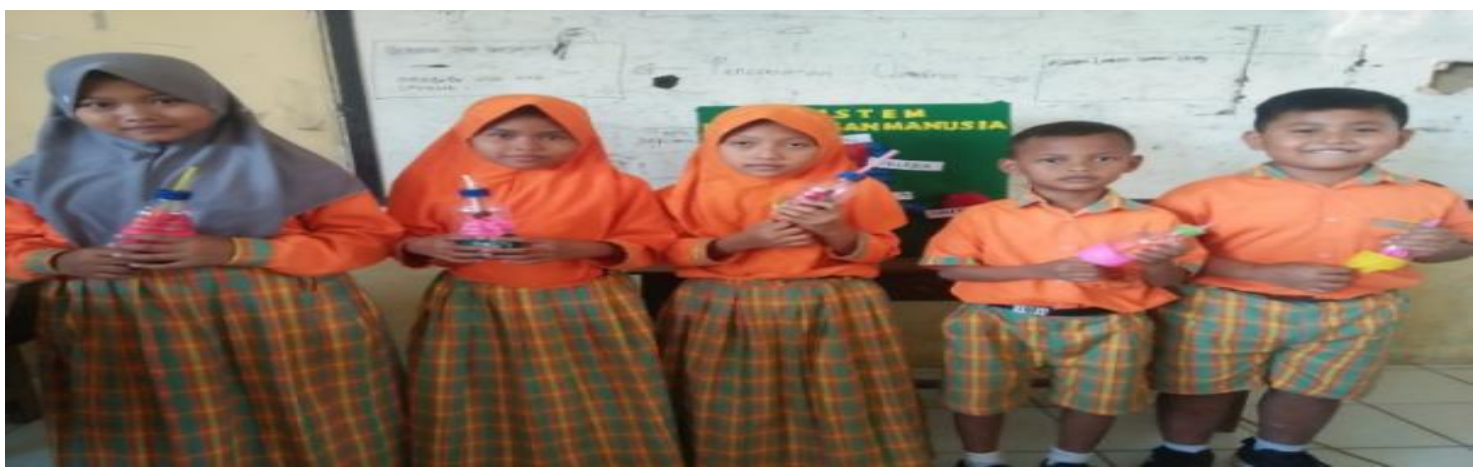

Figure 1. Respiratory system produced by students in the PjBL-STEM learning model 
Aspects of the STEM approach include student product outcomes that are preceded by Science (S) in the form of material taught is science then Technology $(\mathrm{T})$ in the form of utilizing used goods to be used as the next project for Engineering (E) seen during the process of making the project and finally Mathematics (M) which can be seen and can be explained by students of systemic project made whether it is in accordance with the initial description of the respiratory system or not. On the learning outcomes of PjBL-STEM the students are then given posttest to produce the description of the critical thinking skills test (CTST) results of the students is shown in Table 1.

Table 1. The CTST Statistics Description

\begin{tabular}{lll}
\hline Descriptive Statistics & Pretest & Post-test \\
\hline Numbers of the Students & 34 & 34 \\
Average Score & 67.2 & 80.4 \\
Numbers of the students that have mastered. & 18 & 31 \\
The mastery percentage. & $52.9 \%$ & $91.1 \%$ \\
\hline
\end{tabular}

From Table 1, it shows that the average achievement and mastery of the students in both pretest and post-test of the CTST descriptively improve. Then, to find out the effectiveness of the STEM-based PjBL, a hypothesis test was carried out.

In the hypothesis test about the average mastery, it uses the post-test data obtained from $t_{\text {-count }}$. It is 6.805 with a significant level of $5 \%$ and $d k=34$. It is obtained $t_{\text {table }}$ equal to 2.032. Because the score is $t_{\text {count }}>t_{(1-\pi), d k}$ , it denies $H_{0}$. It means the average scores of the students' critical thinking skills taught by STEM-based PjBL are higher than 75. The hypothesis test is about the students' critical thinking skills mastery classically in the class taught by STEM-based PjBL.

The test applied a two-tailed test by looking at the z-count score. Based on the calculation, it is obtained $Z_{\text {count }}=2.154$. Meanwhile, the $Z_{\text {-table }}$ obtains a score of 0.174. Thus, $H_{0}$ is accepted. It means the critical thinking skills of students taught by STEM-based $\mathrm{PjBL}$ is higher than $75 \%$. Meanwhile, in the $\mathrm{N}$-gain test by using pretest and post-test data, it obtains N-Gain score 0.41 . It is categorized as a moderate improvement.

Based on the data analysis, the STEMbased PjBL shows that (1) the students' critical thinking skills average reaches higher than 75 , (2) the classical mastery of the students' critical thinking skills taught by STEM-based PjBL is higher than $75 \%$, and (3) there is improvement after the students were intervened by STEMbased PjBL. Therefore, those three results could be used as indicators of STEM-based $\mathrm{PjBL}$ in Science course for the fifth graders of the primary school. It is proven effective to improve their critical thinking skills.

Based on the data, it shows that STEMbased $\mathrm{PjBL}$ is effective in improving the critical thinking of students. It is in line with research that STEM-based learning approach could improve the critical thinking skills of the students than conventional learning (Khoiriyah, Abdurrahman, \& Wahyudi, 2018). It was also supported by Asri (2018) that the STEM approach in learning improves the critical thinking skills of students.

Project Based Learning (PjBL) facilitated understanding the concept of the students, so they would confident for tested the products they made in the group and presented it in the class (Nugraha, 2018). PjBL and cooperative learning could support the STEM implementation in science learning (Afriana, Permanasari, \& Fitriani, 2016). Gandi, Haryani, \& Setiawan (2019) revealed that STEM-based Project-Based Learning is effective to improve students' critical thinking skills. 
Another study conducted by Prasadi \& Suharini (2020) found that the STEM approach could improved learning communication. The STEM integrated PjBL model has positive responses from the students to scientific literature, creativity, and problem-solving skills. The learning outcomes in STEM integrated $\mathrm{PjBL}$ were better than that of the control group and were effective to apply (Lutfi, Ismail, \& Azis, 2017). The STEM-based Project-Based Learning could improve the average on the students' critical thinking skills (Haryanti \& Suwarma, 2018). The improvement of the critical thinking skills is in line with a study conducted by Lestari and Sumarti (2018). They stated that STEM-based Project-Based Learning could provide students with highorder and creative problem-solving experience. The improvement in dealing with the learning is also emphasized by Purwanti (2015) that students' critical thinking skills will be high when they learn enjoyably.
Meanwhile, the improvements in the students' critical thinking skills were limited to the lowest category because they were enthusiastic about learning new things. They could also interact in the learning because of the group. However, due to the limited numbers of meetings, they made students difficult to adapt (Rochmad \& Ulinnuha, 2020). Therefore, the new learning model applied requires a long time in order to get a high increase. Based on the series of research in STEM approach and PjBL model, it can be concluded that STEM-based Project-Based Learning empirically and theoretically effectively improve critical thinking and communication skills of students.

In this study, students have grouped by their critical thinking skills based on their communication skills. The data is presented in Table2.

Table 2. The Grouping based on Communication Skills

\begin{tabular}{lll}
\hline Categories & Numbers of the Students & Percentage (\%) \\
\hline High & 6 & 18 \\
Moderate & 22 & 64 \\
Low & 6 & 18 \\
\hline
\end{tabular}

The Critical Thinking Skills of students with High Communication Skills Category

The subject with critical thinking skills in the high communication skills category perform various critical thinking skills test results. This is proved by the results of the high communication category subjects' work in Figure 2.

\footnotetext{
11. Andriana suka menyayi di sekolah, ia sering menjadi anggota paduan suara di sekolan. Ketika ia berlatih bernyayi dengan anggota paduan suara, dia menggunakan pernapasan perut. Mengapa kebanyakan penyayi sering menggunakan pernapasan perut dibandingkan menggunakan pernapasan dada? Berikan alasanmu dengan jelas!

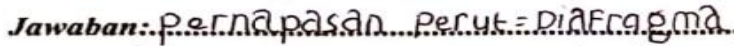

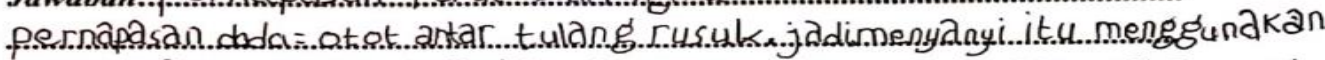
p.e...nap.as.an...diaf..agg.a....bj.ar.dapat.m.engat.ur...per.nap.asa..saat.menyayi ,
}

Figure 2. Critical Thinking Ability Test results from high communication category subjects.

Figure 2 shows that in communication category, students were able to answer with critical thinking skills based on high communication skills, the question discusses about a singer who use abdominal breathing rather than chest breathing. Basically, a singer prefers to use abdominal breathing or diaphragm because it can regulate breathing when singing to breathe more air and make breathing hard, thus making the diaphragm 
stronger and more beautiful sounds. If she use chest breathing the mechanism of breathing air when breathing cannot be properly regulated because it uses muscles between the ribs.

In the Figure 2, students' critical thinking skills with high communication skills category can answer the question and fulfil all indicators of critical thinking skills, although there are deficiencies in the aspects of making and determining the outcome of consideration. Based on observations from students with high skills in the picture above, it was found that students can achieve all of the indicators, it was corroborated by footage of interviews with the following subjects.

$\mathrm{P}$ : Why do you answer like that?

S-22 : Because I also practice singing, and I feel if singing is the breath that is used is the stomach, and I used to make assignments from the teacher via a used bottle from the stomach if the breathing is diaphragm.

From the results of the interview, students with high skills answer because they practice breathing while singing, therefore from the results of observations and interviews about the answers students can already think critically according to indicators one of them by practicing and learning PjBLSTEM also helps students in understanding the material. Indicator (a) focusing the question on the figure the student can answer "abdominal breathing = diaphragm", the

\section{The Critical Thinking Skills of Students in Moderate Communication Skills Category}

The subject with critical thinking skills in the moderate communication skills category were the most dominant. It shows different results of critical thinking skills test. There were several of them having high student is already focusing on the goal which is answering the question about using abdominal breathing. Indicator (b) in the aspect of analyzing arguments, student can answer two differences in diaphragmatic breathing and what abdomen and organs are used. Indicator (c) the aspects of asking and answering questions, the answer was correct and focus on the questions given. Indicator (d) provide a simple explanation, student can determine the proper breathing used by a singer, namely by breathing the stomach and its reasons; while in indicator (e) on making and determining the results of consideration, student

can answer diaphragmatic breathing, even though without explaining the meaning of chest breathing. Indicator (f) on the aspect of make conclusions and (g) testing their conclusions, student was able to answer appropriately that is the answer to the use of breathing the stomach can result in being able to regulate the singer when singing.

From the results in the student' communication skills with high category, it was found that student could solve all critical thinking skills questions excellently. It is in line with Arviani \& Fajriyah (2018), stating that if the students' communications are high, then the learning outcomes will be better. Iman, Isnaeni, \& Ellianawati (2020) stated that the students' communication skills will be better by promoting technology-based learning under 21st-century development. scores in critical thinking indicator while the others were having low scores. In the moderate communication skills category, subjects with the lowest and the highest critical thinking skills scores were selected. This was indicated by the results of the subject's work in Figure 3. 


\section{Andriana suka menyayi di sekolah, ia sering menjadi anggota paduan suara di sekolah.} Ketika ia berlatih bernyayi dengan anggota paduan suara, dia menggunakan pernapasan perut. Mengapa kebanyakan penyayi sering menggunakan pernapasan perut dibandingkan menggunakan pernapasan dada? Berikan alasanmu dengan jelas!

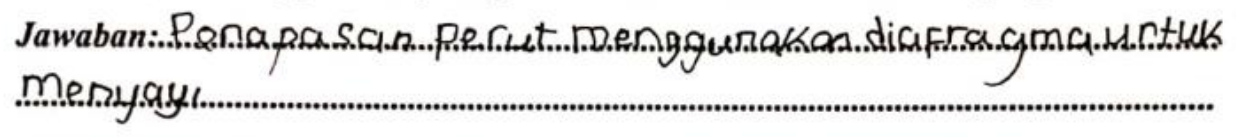

Figure 3. Critical Thinking Ability Test results from moderate communication category subjects.

In Figure 3, information was obtained that students with critical thinking skills in the category of moderate communication skills could answer a problem of critical thinking skills, although there are deficiencies in the aspects of focusing questions, analyzing arguments, making and determining the outcome of consideration.

Based on observations from students with the moderate skills in the picture above it is found that students can achieve several indicators, namely asking and answering questions, Making and determining the results of considerations, simple explanation, drawing conclusions, testing similarities and conclusions, it was corroborated by the following interview excerpts from the subject.

$\mathrm{P}$ : According to you, how is the breathing of the abdominal and chest breathing?

S-20 : Abdominal breathing uses muscles between the ribs, for chest breathing using a diaphragm.

From the results of the interview, students with the skill of moderate answered because the students 'understanding when explained was not paying attention well. Therefore, the results of observations and interviews about students' answers were able to think critically from several indicators one of them by asking and answering questions in $\mathrm{PjBL}$ learning -STEM also helps students understand the material.

The moderator level of communication of student provided the details on indicators (a) focusing the question on the Figure 3 of the student is not quite right in answering "chest breathing $=$ muscle between the ribs" which should be "abdominal breathing = diaphragm". It made student less focused on the goal which is answering questions about the use stomach breathing. Indicator (b) in the aspect of analyzing the argument, student was not quite right in answering the two differences in diaphragmatic breathing and what stomach and organs are used. Indicator (c) in the aspect of asking and answering questions student have already answered but the answers were not right and in indicator (d) giving a simple explanation student can determine the proper breathing used by a singer that is by breathing the stomach and its reasons. Indicator (e) in making and determining the results of consideration, student can answer diaphragmatic breathing, even without explaining the meaning of chest breathing. Indicator (f) on the aspect of make conclusions student can provide answers correctly so that student focus on human breathing material. Indicator (g) testing their conclusions, student have given answers correctly so students understand abdominal breathing.

From the analyzes in the students' communication skills with moderate category, there were some of them could complete all questions of critical thinking skills excellently. However, there were some of them still poor in completing the questions. It is in line with $\mathrm{Pal}$, Halder, \& Guha (2016) that communication skills is one thing that has important roles in children' lives. Through proper communication, students could deliver their thoughts to other 
people both in written and spoken modes with high score achievement.

The Critical Thinking Skills of Students in Low Communication Skills Category

The subject with critical thinking skills in the low communication skills category perform similar critical thinking skills test results. The results tend to be lower. In the low communication skills category, two subjects were selected based on low and high critical thinking skills. This is indicated by the results of a sampel of subject work in Figure 4.

\section{Andriana suka menyayi di sekolah, ia sering menjadi anggota paduan suara di sekolah.}

Ketika ia berlatih bernyayi dengan anggota paduan suara, dia menggunakan pernapasan perut. Mengapa kebanyakan penyayi sering menggunakan pernapasan perut dibandingkan menggunakan pernapasan dada? Berikan alasanmu dengan jelas!

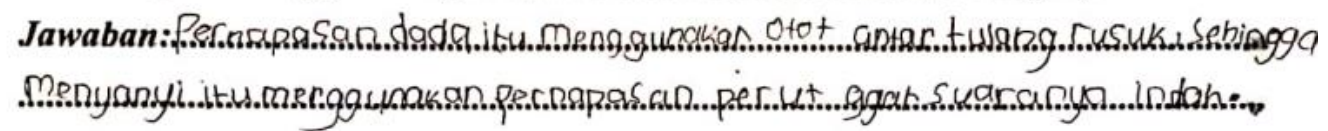

Figure 4. Critical Thinking Ability Test results from low communication category subjects

As displayed in Figure 4, information is obtained that student with critical thinking skills in the category of low communication skills can answer a question of critical thinking skills, although there are deficiencies in the aspects of analyzing arguments, asking and answering questions, making and determining the outcome of consideration, drawing conclusions and testing conclusions.

Based on observations from students with low skills in the picture above it is found that students can achieve several indicators, namely, focusing questions and making and determining the results of consideration, it is corroborated by footage of interviews with the subject as follows.

$\mathrm{P}$ : What if the singer breathes using chest breathing?

S-2 : Yes, that's more appropriate. Because it can produce good sound

From the results of the interview, students with low skills answered incorrectly from the questions given, therefore from the results of observations and interviews about students' answers only reached two indicators of critical thinking namely focusing the question and making and determining the outcome of consideration. In the indicator (a) focusing the questions, the student was right in answering "abdominal breathing = diaphragm", it makes students focus on the goal that is answering questions about the use of abdominal breathing. Indicator (b) but on the aspect of analyzing the argument, student was not right answering one difference in breathing, students only know one breathing that is abdominal breathing and what organs are used. Indicator (c) in the aspect of asking and answering student did not provide an explanation and was less precise in providing explanations, while in indicator (d) in the aspect of simple explanation student was less able to provide explanations on abdominal breathing. Indicator (e) on making and determining the results of consideration, student respond to diaphragmatic breathing, but do not explain the meaning of chest breathing. Indicator (f) on the aspect of make conclusions and (g) on testing their conclusions, student was not giving simple explanation so that the conclusion in answering is not right.

From the results in the students' communication skills with the low category, it was found all students could not solve all critical thinking skills questions excellently. It is in line with Natalle \& Crowe (2013) research that difficulties in communicating hindered students to master competence.

\section{CONCLUSION}


Based on the analysis results and the discussion, it is proven that STEM-based Project-Based Learning is effective in improving critical thinking of students. The descriptions of the critical thinking skills based on the students' communication skills seen from their initial skills show various results. It means the students' critical thinking skills influence their communication skills.

\section{REFERENCES}

Afriana, J., Permanasari, A., \& Fitriani, A. (2016). Penerapan Project Based Learning Terintegrasi STEM untuk Meningkatkan Literasi Sains Siswa ditinjau dari Gender. Jurnal Inovasi Pendidikan IPA. 2(2): 202212.

Arviani, I., \& Fajriyah, K. (2018). Keefektifan Model Show and Tell untuk Meningkatkan Keterampilan Berkomunikasi pada Materi Proklamasi Kemerdekaan Siswa Kelas V SD Negeri Babalan. Al Ibtida: Jurnal Pendidikan Guru MI. 5(1): 1-13.

Asri, Y. N. (2018). Pembelajaran Berbasis Stem Melalui Pelatihan Robotika. Journal WaPFi (Wahana Pendidikan Fisika). 3(2): 65-74.

Becker, K. H., \& Park, K. (2011). Integrative Approaches among Science, Technology, Engineering, and Mathematics (STEM) Subjects on Students Learning: A MetaAnalysis. Journal of STEM Education. 12(5 \& 6): 23-37.

Capraro, R. M., Capraro, M. M., \& Morgan, J. R. (Eds.). (2013). STEM project-based learning: An integrated science, technology, engineering, and mathematics (STEM) approach. Springer Science \& Business Media.

Ennis, R. H. (2011). The nature of critical thinking: An outline of critical thinking dispositions and abilities. In Sixth International Conference on Thinking, Cambridge, $M A$ (pp. 1-8).

Gandi, A. S. K., Haryani, S., \& Setiawan, D. (2019). The Effect of Project-Based
Learning Integrated STEM Toward Critical Thinking Skill. Journal of Primary Education. 10(1): 18-23.

Han, Capraro, R., \& Capraro, M. M. (2015). How Science, Technology, Engineering, and Mathematics (STEM) Project-Based Learning (PBL) Affects High, Middle, and Low Achievers Differently: The Impact of Student Factors on Achievement. International Journal of Science and Mathematics Education. 13(5): 1089-1113.

Haryanti, A., \& Suwarma, I. R. (2018). ISSN : 2338-1027 Februari 2018 Profil Keterampilan Komunikasi Siswa SMP Dalam. JurnalWahana Pendidikan Fisika. 3(1): 49-54.

Hartini, A. (2017). Pengembangan Perangkat Pembelajaran Model Project Based Learning Untuk Meningkatkan Kemampuan Berpikir Kritis Siswa Sekolah Dasar. ELSE (Elementary School Education Journal): Jurnal Pendidikan dan Pembelajaran Sekolah Dasar, 1 (2): 3-7.

Iman, N. N., Isnaeni, W., \& Ellianawati. (2020). Analysis of Communication Skills and Empathy of Fifth-Grade Students of Elementary Schools through ICT-based Learning Article Info. Journal of Primary Education. 9(3): 321-327.

Jauhariyyah, F. R., Suwono, H., \& Ibrohim. (2017). Science, Technology , Engineering and Mathematics Project Based Learning ( STEM-PjBL ) pada Pembelajaran Sains. Pros. Seminar Pend. IPA Pascasarjana UM 2:(1): 432-436. Yogyakarta, Juni 2017.

Khoiriyah, N., Abdurrahman, A., \& Wahyudi, I. (2018). Implementasi pendekatan pembelajaran STEM untuk meningkatkan kemampuan berpikir kritis siswa SMA pada materi gelombang bunyi. Jurnal Riset Dan Kajian Pendidikan Fisika. 5(2): 44-53.

Lestari, D. A. B., Astuti, B., \& Darsono, T. (2018). Implementasi LKS dengan pendekatan STEM (science, technology, engineering, and mathematics) untuk meningkatkan kemampuan berpikir kritis 
siswa. Jurnal Pendidikan Fisika dan Teknologi, 4(2): 202-207.

Lestari, T. P., \& Sumarti, S. S. (2018). STEMBased Project Based Learning Model to Increase Science Process and Creative Thinking Skills of 5th Grade. Journal of Primary Education. 7(1): 18-24.

Lutfi, Ismail, \& Azis, A. A. (2017). Pengaruh project based learning terintegrasi stem terhadap literasi sains, kreativitas dan hasil belajar peserta didik. Prosiding Seminar Nasional Biologi Dan Pembelajarannya. 189-194.

Mutakinati, L., Anwari, I., \& Kumano, Y. (2018). Analysis of students' critical thinking skill of middle school through stem education project-based learning. Jurnal Pendidikan IPA Indonesia, 7(1): 54-65.

Natalle, E.J., \& Crowe, K.M. (2013). Information literacy and communication research: A case study on interdisciplinary assessment. Communication Education, 62 (1): 97-104.

Nugraha, S. (2018). Penguasaan Konsep Ipa Siswa Sd Dengan Menggunakan Model Problem Based Learning. EduHumaniora. Jurnal Pendidikan Dasar Kampus Cibiru. 10(2): 115-127.

Ongardwanich, N., Kanjanawasee, S., \& Tuipae, C. (2015). Development of 21st century skill scales as perceived by students. Procedia-Social and Behavioral Sciences. 191(52): 737-741.

Pal, N., Halder, S., \& Guha, A. (2016). Study on Communication Barriers in the Classroom: A Teacher's Perspective. Journal of Communication and Media Technologies. 6(1): 103-118.

Prasadi, A. H., \& Suharini, E. (2020). The Implementation of Student Worksheet Based on STEM ( Science, Technology , Engineering , Mathematics ) and Local Wisdom to Improve of Critical Thinking Ability of Fourth Grade Students. Journal of Primary Education. 9(3): 235-245.
Purvis, C., Mc Neill, B., \& Sutherland, D. (2014). Language, communication, and literacy skills of adolescents with behavioral difficulties in mainstream education. Speech, Language, and Hearing. 17 (4): 225-236

Purwanti, S. (2015). Meningkatkan Kemampuan Komunikasi dan Berpikir Kritis Matematis Siswa Sekolah Dasar Dengan Model Missouri Mathematics Project (MMP). Jurnal Pendidikan Dan Pembelajaran Dasar. 2(2): 253-266.

Rochmad, \& Ulinnuha, R. (2020). Blended Learning Menggunakan Gnomio untuk meningkatkan Kemampuan berpikir kreatif matematis siswa SMP. Prisma, Prosiding seminar nasional matematika. 3(1): 746-481

Rochmawati, A., Wiyanto, \& Ridlo, S. (2019). Analysis of 21th Century Skills of Student on Implementation Project Based Learning and Problem Posing Models in Science Learning. Journal of Primary Education. 9(1): 58-67.

Nugroho, O. F., \& Nurcahyo, M. A. (2018). Analisis Literasi Pendidikan STEM pada Siswa dan Pemahaman Konsep IPA Melalui Peta Konsep di SDN Palasari II. Thabiea: Journal of Natural Science Teaching, 1(2): 121-124.

Siregar, Y. E. Y., Rachmadtullah, R., Pohan, N., \& Zulela, M. S. (2019). The impacts of science, technology, engineering, and mathematics (STEM) on critical thinking in elementary school. In Journal of Physics: Conference Series (Vol. 1175, No. 1, p. 012156). IOP Publishing.

Wijayanti, A. I., Pudjawan, K., \& Margunayasa, I. G. (2015). Analisis Kemampuan Berpikir Kritis Siswa Kelas V Dalam Pembelajaran Ipa Di 3 Sd Gugus $X$ Universitas Pendidikan Ganesha. E-Journal PGSD Universitas Pendidikan Ganesha. 3(1): 1-12. 